\title{
Employee perceptions of organisational democracy and its influence on organisational citizenship behaviour
}

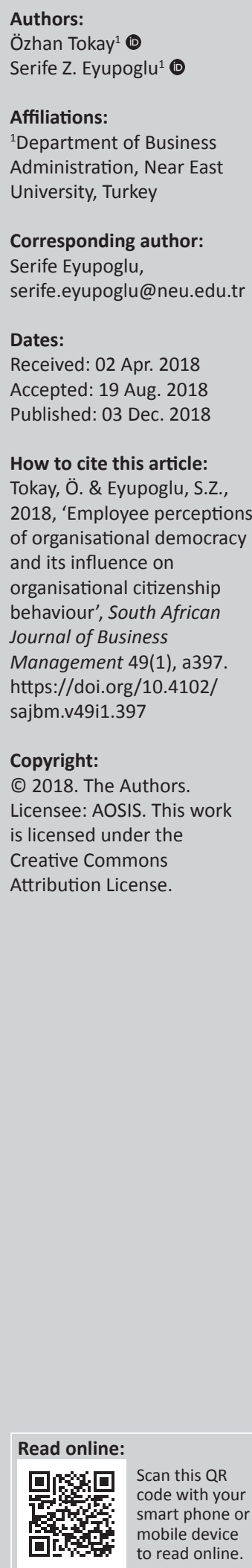

Background: It has been said that organisational democracy influences the improvement of behavioural orientations related to being good organisational citizens.

Objectives: The main purpose of this study was to provide empirical evidence on bank employees' perceptions towards organisational democracy and their organisational citizenship behaviour, in addition to indicating whether a relationship exists between organisational democracy and organisational citizenship behaviour.

Method: Data were collected through the use of a questionnaire. The population of the study consisted of bank employees working at branches of a private bank located in the province of Istanbul, Turkey. A total of 240 bank employees took part in the study. Data analysis entailed the computation of descriptive statistics, as well as $t$-test, analysis of variance (ANOVA) test, correlation analysis and regression analysis.

Results: The study results indicated that a statistically significant relationship exists between the bank employees' perceptions of organisational democracy and their organisational citizenship behaviour.

Conclusion: Through this study, it can be concluded that organisational democracy is an important variable that can be used by managers to facilitate the favourable behaviour of employees and to promote the sense of citizenship that employees feel towards their organisation, which in turn will positively influence organisational performance.

\section{Introduction}

Organisational democracy (OD) is a management approach in which employees are involved in the decision-making and management process, where participation, discussion and consensus are maintained, mutual communication and solidarity are strengthened, managers have responsibility to the personnel and the understanding of acting in unity is presented (Harrison \& Freeman 2004; Kerr \& Caimano 2004; Weber, Unterrainer \& Schmid 2009; Yazdani 2010). Organisational democracy has been strongly linked to enhanced levels of job satisfaction, an increase in organisational performance, improved innovation as well as extra-role behaviour displayed by employees. This extra-role behaviour is known as organisational citizenship behaviour (OCB). Likewise, $\mathrm{OCB}$ is also said to increase organisational productivity, ensure that high-performing employees remain in the organisation, ensure organisational performance and assist in adapting to organisational change more quickly. Organisational citizenship behaviour relates to the kind of behaviours that are not assigned to any individual by the formal structure of organisation and yet the individual exhibits discretionally with no expectation of reward. Employees' reactions in their organisation are expected to affect the degree to which they will go past the call of duty (Somech \& Drach-Zahavy 2004).

Numerous studies have investigated OCB in manufacturing organisations (Morrison 1994). Service-oriented OCB has been somewhat ignored (Yoon \& Suh 2003); however, with the growth of the service industry, the behaviour of service-oriented employees' has come to light. Serviceoriented employees are constantly engaged in direct contact with their customers (Bartel 2004); therefore, the OCB of service-oriented employees can increase their performance and enhance service quality. Even though there is a lack of research on the influence of OD on individual behaviours, research on other organisational practices exists and indicates the influences of these practices on creating positive behaviour, which has been seen to improve organisational performance. The banking sector is a service-oriented sector in which performance is realised through providing superior customer service. However, research on OCB in the banking sector is not very evident in the literature and represents a significant gap. In this sense, the main objective 
of this study is to explore whether OD influences the improvement of behavioural orientations consistent with being dependable organisational citizens in the service industry. The study is conducted amongst employees working in the banking sector, a highly labour-intensive sector that requires OCB to ensure superior customer services, indicating the worthiness of the study. The authors intend to fill the gap in the literature with respect to OD and OCB in service-oriented organisations.

\section{Theoretical framework and hypothesis development Organisational democracy}

It is important for employees that democratic principles are applied in the organisation and when employees are given the opportunity to have a say in the daily operations of their organisation, they will improve their performance through reducing their non-functional behaviour. Employees will be more concentrated on working on the organisation's wellbeing as well as improving their knowledge and skills (Coşan \& Gülova 2014). The understanding of joining governance in organisations is the most important issue in the name of OD.

However, it is only when OD is present in organisational life with all of its dimensions that it will create synergy and provide benefits for organisations (Geçkil \& Tikici 2016). According to Geçkil and Tikici (2015), the five dimensions of OD can be listed as participation-criticism, transparency, justice, equality and accountability.

Participation refers to the involvement (directly or through representatives) of employees with all decision-makingrelated processes (Geçkil \& Tikici 2015). Employees' participation in management decisions and playing a part in deciding on their role in the future of the organisation through expressing their ideas about the organisation makes them feel that they are a part of the organisation (Tutar \& Sadykova 2014). Participation positively influences employees' attitudes towards their organisation (Hendry 2012). Studies have also shown that participation in decisionmaking can lead to extra-role behaviour (Porter, Lawler \& Hackman 1996). Criticism denotes employees having the ability to evaluate policies, procedures and work as well as having the freedom to evaluate and provide suggestions (Geçkil \& Tikici 2015). It involves employee opinions being valued and encouraged with decisions being made based on mutual understanding (Bakan, Kara \& Güler 2017). Democratic organisations must also be favourable towards self-criticism and be transparent towards self-sustaining evolution as well as providing favourable settings for discussions and solutions (Geçkil \& Tikici 2015). The 'transparency' dimension of OD refers to the ability of all members involved to access all the information used to make a specific decision (Forcadell 2005). It is the learning and monitoring of work and processes as well as work-related decisions by all affected parties (Geçkil \& Tikici 2015). In democratic organisations, information mustbecommunicated to all groups and opinions of all members should be considered. Information sharing practices may cause employees to perceive that the organisation values their contributions to accomplish goals and support the organisation through modifying their behaviour and displaying extra efforts (Shore \& Barksdale 1998). Justice refers to the rules and social norms related to the system that regulates how to manage and distribute the emerging rewards and punishments (Yildirim 2003). Organisational justice deals with perceptions on equality in organisational decisions and decision-making processes and examines the perceptions of employees on the level of equal treatment in their organisation (Geçkil \& Tikici 2015). An important motivational factor for extra-role behaviour is the perception of fairness, especially the perceptions of justice in the workplace (Organ \& Ryan 1995). Equality denotes the equilibrium between two or multiple quantities of entities and relates to endowing two parties with identical rights and advantages (Geçkil \& Tikici 2015). Equality involves not exposing individuals to discrimination about issues such as religion, language, race, gender, world view and having equal opportunities to acquire same rights in all individuals (Kesen 2015). The accountability dimension refers to accepting liability for the consequences of certain actions and involves providing insights and defence if necessitated by the particular case (Lindkvist \& Llewellyn 2003). Accountability also denotes accounting for established decisions, expenditures and miscellaneous savings of the organisation in addition to asking for clarification on related items (Geçkil \& Tikici 2015). Few studies have empirically examined the relationship between accountability and performance or behaviour; however, positive relationships have been found to exist between accountability and prosocial behaviour (Mitchell et al. 1998).

\section{Organisational citizenship behaviour}

The issue of OCB has gained significant attention over the years and has been researched in a variety of settings because of its contribution to the effective functioning of organisations (Eyupoglu 2016). In today's competitive world, thriving organisations are those whose employees carry out duties beyond their formal contract (Ali \& Waqar 2013). Although the concept of OCB stretches back as far as Katz and Kahn (1966), the concept is pioneered by Dennis Organ (1988). According to Organ (1988), OCB is individual behaviour that is discretionary, not directly or explicitly recognised by the formal reward system and that in the aggregate promotes the effective functioning of the organisation. Because OCB is voluntary, employees who engage in OCB are not usually rewarded for doing so (Organ 1988). Employees with a sense of citizenship work together in harmony and support each other's productivity (Akdoğan \& Köksal 2014; Basım \& Şeşen 2015). There is a differentiation between official organisational behaviour and OCB. Behaviours that are not official can be described as OCB or 'good soldier syndrome' (Organ 1988), which means that employees withhold from undesirable behaviour such as being late, criticising others in the 
workplace and absenteeism. Organisational citizenship behaviour includes constructive and positive behaviours such as supporting organisational goals and objectives, providing cooperation within an organisation and keeping organisational interests above the interests of employees (Borman \& Motowidlo 2014). Graham (1991) asserts that OCB cannot possibly be limited to extra-role behaviours and in fact argues that OCB is a global term harnessed to define all behaviours towards the organisation. According to Organ (1988), OCB can be conceptualised as consisting of five dimensions which are altruism (e.g. helping others who have to deal with heavy workloads), conscientiousness (e.g. work behaviour and attendance that can be regarded as above the norm level), sportsmanship (e.g. tending not to complain about trivial matters), courtesy (e.g. consulting with others before taking action) and civic virtue (e.g. participation in the political process of the organisation). Altruism is concerned with going beyond job requirements to help others with whom the individual comes into contact (Redman \& Snape 2005), and the selflessness of an employee towards their organisation. It comprises behaviour emphasising the group over the individual's concerns. Conscientiousness emphasises responsibility and dedication. It involves taking the initiative to engage in behaviour for the good of the organisation (King, George \& Hebl 2005). Sportsmanship includes tolerating inconveniences at the workplace without complaining. Workers are less distracted from their tasks because they avoid negative behaviour. Courtesy behaviour may be categorised as preventive measures to ensure organisational efficiency (Geçkil \& Tikici 2015) through positive communication with all the members interacting in an organisation. Civic virtue is the behaviour that reflects in employees identifying strongly with their organisation and making purposeful contributions. It involves the indication of a responsible concern for the image and well-being of the organisation (Redman \& Snape 2005).

An examination of the literature shows that this fivedimension framework suggested by Organ (1988) has received extensive attention and has been a support in many empirical studies (LePine, Erez \& Johnson 2002). Podsakoff et al. (2000) conclude that OCB's influence on organisational performance can be categorised into seven areas: to increase the effectiveness of colleagues and managers, to release resources for more productive activities and objectives, to decrease the scarce resources needed for the upkeep of the normal operation of the organisation, to support the coordination between work groups and within groups, to reinforce the ability for the organisation to attract and retain able employees, to improve the stability of the organisation and to make organisations more receptive to change in the environment.

\section{The organisational democracy and organisational citizenship behaviour relationship}

The social exchange theory presumes that employees feel an obligation to repay their organisation's support and make their best efforts towards effective organisational performance
(Park \& Searcy 2012). In this sense, OD and OCB are perceptions that support each other. Participation of employees in organisational decisions and taking part in the organisation's future will increase their positive attitudes towards the organisation. Participation in the decisionmaking process influences how employees assess the fairness of procedure (Folger 1977). Employees in democratic organisation structures will feel themselves as a part of the organisation. This situation will strengthen the behaviour of organisational citizenship by ensuring that employees put their organisation's benefits above and beyond their own benefits. In organisations where perceptions of justice are high, perceptions of citizenship behaviour will also be high (Akdoğan \& Köksal 2014; Boxall \& Purcell 2011). When employees see themselves as being treated equally, one possible way to repay the organisation is through greater citizenship behaviours (Konovsky \& Pugh 1994). In addition, the opportunity to provide suggestions, comment and criticise procedures and methods implies that management respect the rights of their employees and they are willing to contemplate the suggestions and complaints from employees. High-quality relationships between supervisor and subordinates are also linked to OCB (Deluga 1995; Farh, Earley \& Lin 1997). The degree of dissemination of work and procedures and work-related decisions to all concerned parties within an organisation demonstrates how transparent an organisation is and strengthens the trust between employees and the organisation, thus most probably encouraging the extra-role behaviour of employees. Likewise, the sincerity of an organisation to clarify, advocate or explain all the accomplished procedures or activities to employees reflects its responsibility towards its employees, and is also expected to reflect on employees' positive behaviour (Harrison \& Edward 2004). On the whole, OD makes employees feel more responsible for their work because they take on more ownership of their work (Harrison \& Edward 2004) and, hence, are more willing to exhibit citizenship behaviour.

In this respect, the study proposes the following hypotheses:

- H1: Employee perception of overall OD positively influences their OCB.

- H1a: Employee perception of 'participation-criticism' positively influences their OCB.

- H1b: Employee perception of 'transparency' positively influences their OCB.

- H1c: Employee perception of 'justice' positively influences their OCB.

- H1d: Employeeperception of 'equality' positively influences their OCB.

- H1e: Employee perception of 'accountability' positively influences their OCB.

\section{Methodology Study variables and instrument}

The model of the research is descriptive and cross-sectional. The questionnaire consisted of three parts: demographic 
information, the Organisational Democracy Scale (ODS) and the Organisational Citizenship Behaviour Scale (OCBS). The ODS used in this study was developed by Geçkil and Tikici (2015). This scale consists of 28 items that are divided into five sub-dimensions: participation-criticism, transparency, justice, equality and accountability. Participation-criticism is measured through eight items (items 1-8) with a Cronbach's alpha score of 0.82 . Transparency is measured through six items (items 9-14) with a Cronbach's alpha score of 0.81 . Justice is measured through five items (items 15-19) with a Cronbach's alpha score of 0.83 . Equality is measured through six items (items 20-25) with a Cronbach's alpha score of 0.78 and accountability is measured through three items (items 26-28) with a Cronbach's alpha score of 0.77 . The Cronbach's alpha value for the dimension OD (the total of the 28 items of the ODS) is measured as 0.79. The suggested level of Cronbach's alpha is 0.7 and a data set needs to achieve at least this level of reliability to be an acceptable study (Hair et al. 2006). Therefore, the Cronbach's alpha scores for the OD variable and all of its sub-dimensions for this study are reliable. Respondents were asked to identify the degree of their agreement and disagreement with each of the 28 items on a five-point Likert scale extending from 1 (strongly disagree) to 5 (strongly agree). Some sample questions from the ODS are as follows: 'managers encourage me to participate in organisational decisions', 'the opinions of the majority are taken into account in institutional decision-making' and 'when decisions are made at the institution, everyone who will be affected by those decisions has the right to speak'.

The OCBS used in this study was developed by Podsakoff et al. (1990). The reliability and validity in Turkish were conducted by Ünüvar (2006). The OCBS consists of 24 items that are divided into five sub-dimensions: altruism, conscientiousness, courtesy, sportsmanship and civic virtue. This study only considered the overall OCB variable. The Cronbach's alpha value for the OCBS (the total of the 24 items) was calculated as 0.80 . This value is also considered to be reliable. As with the ODS, the respondents were asked to express the degree of their agreement and disagreement with each of the 24 items on a five-point Likert scale extending from 1 (strongly disagree) to 5 (strongly agree). Some sample questions from the ODS are as follows: 'I help people with heavy workloads', 'I do not take extra breaks' and 'I believe in giving an honest day's work for an honest day's pay'.

\section{Sample and procedure}

The study population consisted of bank employees working at branches of a private bank located in the province of Istanbul, Turkey. The bank has a total of 600 employees in its Istanbul branches. According to Sekaran and Bougie (2013), a sample size of 274 is suitable for a population of 600 . Consequently, a total of 280 bank employees were randomly selected to take part in the study. Of the 280 questionnaires distributed, 247 were returned of which 240 were applicable for analysis, thereby yielding a response rate of $86 \%$. The questionnaire was applied between March and May 2017.
Questionnaires were distributed to the respondents by the authors through e-mails as a booklet, clearly explaining the purpose of the study. Participation was voluntary. In the booklet, it was emphasised that the study was for scientific purposes and that the respondents' identities would be strictly held confidential.

\section{Results \\ Profile of respondents}

The majority of the respondents (51.7\%) were male, $53.3 \%$ had undergraduate degrees, $38.3 \%$ were between the age of 40 and 49 years, $64.2 \%$ were married and $35 \%$ had experience in the banking sector of 11-15 years (see Table 1).

\section{Mean scores and reliabilities of the study variables}

The Kolmogorov-Smirnov test was conducted to measure the goodness-of-fit of the sample from the population. As Table 2 indicates, the ODS and all of its sub-dimensions were found to fulfil the assumption of normal distribution $(p>0.05)$.

Table 2 also indicates the respondents' mean total scores for OD was $3.40(S D=0.88)$. When the sub-dimensions are examined, it can be seen that respondents indicated 'transparency' with the highest mean score of $3.63(S D=0.92)$ and the lowest mean score of 3.21 was indicated for the subdimension of 'equality'. Even though the entire mean scores for all the variables are above the 3.00 mid-point score, the mean scores cannot be considered satisfactory. In other words, the respondents' perceptions of OD can only be

TABLE 1: Demographical profile of respondents

\begin{tabular}{lcc}
\hline Variables & Frequency & Percentage \\
\hline Gender & 116 & \\
Female & 124 & 48.3 \\
Male & 240 & 51.7 \\
Total & & 100.0 \\
Educational status & 25 & \\
Associate degree & 128 & 10.4 \\
Undergraduate & 87 & 53.3 \\
Postgraduate & 240 & 36.2 \\
Total & & 100.0 \\
Age & 32 & \\
20-29 years & 78 & 13.3 \\
30-39 years & 92 & 32.5 \\
$40-49$ years & 38 & 38.3 \\
50 years and over the age of 50 years & 240 & 15.8 \\
Total & & 100.0 \\
Marital status & 86 & \\
Single & 154 & 35.8 \\
Married & 240 & 64.2 \\
Total & & 100.0 \\
Experience in banking sector & 32 & 33.3 \\
1-5 years & 84.0 \\
11-15 years & & 100.0 \\
Total & & \\
\hline & & \\
\hline
\end{tabular}


TABLE 2: Organisational democracy and organisational citizenship behaviour Kolmogorov-Smirnov test results.

\begin{tabular}{lccc}
\hline Variables and dimensions & Mean score (X) & Standard deviation (SD) & Normal distribution ' $Z^{\prime}$ \\
\hline OD & 3.40 & 0.88 & 0.981 \\
Participation-criticism & 3.28 & 0.85 & 0.620 \\
Transparency & 3.63 & 0.92 & 0.235 \\
Justice & 3.34 & 0.84 & 0.724 \\
Equality & 3.21 & 0.782 & 0.836 \\
Accountability & 3.54 & 0.92 & 0.391 \\
OCB & 3.52 & 0.97 & 0.312 \\
\hline
\end{tabular}

$\mathrm{OD}$, organisational democracy; $\mathrm{OCB}$, organisational citizenship behaviour.

TABLE 3: Perception of organisational democracy and organisational citizenship behaviour according to personal characteristics.

\begin{tabular}{|c|c|c|c|c|c|c|c|}
\hline Variables & Participation-criticism ${ }^{a}$ & Transparency $^{a}$ & Justice $^{a}$ & Equality $^{\mathrm{a}}$ & Accountability $^{a}$ & $O D^{a}$ & OCB $^{\text {a }}$ \\
\hline \multicolumn{8}{|l|}{ Gender } \\
\hline Female & 3.12 & 3.68 & 3.57 & 3.14 & 3.73 & 3.44 & 3.69 \\
\hline Male & 3.04 & 3.74 & 3.53 & 3.02 & 3.67 & 3.40 & 3.63 \\
\hline $\mathrm{t}$ & 0.662 & 0.452 & 0.443 & 1.544 & 0.742 & 0.821 & 0.744 \\
\hline$p$ & 0.509 & 0.652 & 0.659 & 0.124 & 0.459 & 0.358 & 0.458 \\
\hline \multicolumn{8}{|l|}{ Educational status } \\
\hline Assoc. degree & 3.17 & 3.80 & 3.62 & 3.11 & 3.75 & 3.49 & 3.24 \\
\hline Undergraduate & 3.03 & 3.69 & 3.52 & 3.07 & 3.68 & 3.39 & 3.64 \\
\hline Postgraduate & 3.04 & 3.61 & 3.48 & 3.03 & 3.71 & 3.74 & 3.71 \\
\hline f & 0.569 & 0.427 & 0.505 & 0.197 & 0.213 & 1.520 & 0.468 \\
\hline $\mathrm{p}$ & 0.567 & 0.653 & 0.604 & 0.821 & 0.808 & 0.128 & 0.627 \\
\hline \multicolumn{8}{|l|}{ Age } \\
\hline 20-29 years & 3.30 & 3.86 & 3.59 & 3.21 & 3.71 & 3.53 & 3.67 \\
\hline 30-39 years & 3.06 & 3.67 & 3.50 & 3.08 & 3.51 & 3.36 & 3.59 \\
\hline 40-49 years & 3.03 & 3.69 & 3.58 & 3.13 & 3.95 & 3.47 & 3.74 \\
\hline 50 years or more & 3.09 & 3.78 & 3.47 & 2.87 & 3.54 & 3.35 & 3.68 \\
\hline$f$ & 0.873 & 0.543 & 0.459 & 1.030 & 0.822 & 0.928 & 0.981 \\
\hline$p$ & 0.418 & 0.652 & 0.718 & 0.341 & 0.410 & 0.367 & 0.421 \\
\hline \multicolumn{8}{|l|}{ Marital status } \\
\hline Single & 3.17 & 3.80 & 3.62 & 3.11 & 3.75 & 3.49 & 3.69 \\
\hline Married & 3.03 & 3.69 & 3.52 & 3.07 & 3.68 & 3.39 & 3.63 \\
\hline $\mathrm{t}$ & 1.045 & 0.743 & 0.904 & 0.492 & 0.665 & 1.152 & 0.662 \\
\hline $\mathrm{p}$ & 0.297 & 0.458 & 0.367 & 0.623 & 0.507 & 0.208 & 0.509 \\
\hline \multicolumn{8}{|c|}{ Experience in banking sector } \\
\hline $1-5$ years & 2.70 & 3.39 & 3.44 & 3.00 & 3.50 & 3.20 & 3.54 \\
\hline $6-10$ years & 3.18 & 3.76 & 3.68 & 3.12 & 3.80 & 3.50 & 3.72 \\
\hline $11-15$ years & 3.16 & 3.82 & 3.48 & 3.06 & 3.66 & 3.43 & 3.61 \\
\hline More than 15 years & 3.01 & 3.67 & 3.54 & 3.11 & 3.80 & 3.42 & 3.73 \\
\hline f & 2.060 & 1.311 & 1.165 & 0.350 & 1.551 & 1.321 & 0.846 \\
\hline$p$ & 0.107 & 0.272 & 0.324 & 0.789 & 0.202 & 0.249 & 0.470 \\
\hline
\end{tabular}

$\mathrm{OD}$, organisational democracy; $\mathrm{OCB}$, organisational citizenship behaviour; $\mathrm{t}, t$-statistic; $\mathrm{p}, p$-value; $\mathrm{f}$, F-statistic

a, As a result of the Kolmogorov-Smirnov test, these dimensions were subjected to parametric tests ( $t$-test and ANOVA).

considered as moderate. When Kolmogorov-Smirnov test results of the OCBS are examined, it has been found that the scale fulfils the assumption of normal distribution $(p>0.05)$ (Table 2). The respondents' mean total score for OCB was 3.52 $(S D=0.97)$. This score indicates that employees' perceptions of their OCB were moderate.

The mean scores for OD and its sub-dimension in relation to demographical characteristics are presented in Table 3. When the female respondents are considered, their mean scores are higher when compared to males for all of the OD subdimensions except for 'transparency'. When educational level is considered, respondents with an associate degree indicate the highest mean scores for all of the OD sub-dimensions. Also, the youngest age group indicates the highest mean scores for all of the OD sub-dimensions except for 'accountability'.
The respondents who were not married indicated highest mean scores for all of the OD sub-dimensions when compared to respondents who were married. Respondents with 6-10 years of experience in the banking sector indicated higher levels of mean scores for four of the OD sub-dimensions, except for 'transparency', when compared to the other ranges of years of experience. The overall OD mean score is highest for female respondents, holders of a postgraduate degree, the youngest age group, not married and respondents who have 6-10 years of banking sector experience. Table 3 also indicates that the respondents' perceptions of OD do not vary according to gender, educational status, age, marital status or banking sector experience $(p>0.05)$.

The mean scores for OCB in relation to demographic characteristics can also be seen in Table 3. Female respondents 
indicated higher levels of OCB compared to male respondents. Respondents with a postgraduate degree indicated higher mean scores for OCB. The 40-49 years age group displayed higher levels of OCB as do unmarried respondents. Also, the respondents with the most experience in the banking sector indicated that they display higher levels of OCB. However, no statistically significant relationship was found between OCB and the demographical variables (gender, educational status, age, marital status and banking sector experience) ( $p>$ 0.05).

\section{Correlation and regression results and hypotheses testing}

According to Pearson's correlation test, the relationship between OD, its sub-dimensions and OCB is presented in Table 4 . There is a positive relationship between OD and OCB as well as all of the OD sub-dimensions and OCB $(p<0.04)$.

Of the OD sub-dimensions, 'equality' indicates the highest level of positive correlation with OCB with the relationship being considered as of medium strength $(r=0.404 ; p=0.000)$. The correlation between the OD sub-dimensions of 'justice' $(r=0.329 ; p=0.000)$ and 'accountability' $(r=0.309 ; p=000)$ and OCB are also positive and of medium strength. The relationship between the remaining sub-dimensions, namely 'participation-criticism' $(r=0.245 ; p=0.000)$ and 'transparency' $(r=0.201 ; p=0.000)$, and OCB are also positive; however, the strength of the correlation is weak.

Table 5 displays the regression analysis between the study variables. Hypothesis 1 suggested that employee perception of overall OD positively influences their OCB. As indicated (Table 5), OD perceptions account for 24.5\% (adjusted $\left.\mathrm{R}^{2}=0.245\right)$ of the change in OCB; therefore, this result provides support for $\mathrm{H} 1$.

Of the OD sub-dimensions, 'justice' has the strongest influence $(22.6 \%)$ on $\mathrm{OCB}$, thus providing support for $\mathrm{H} 1 \mathrm{C}$ (employee perception of justice positively influences their OCB). Furthermore, 'equality' predicts $21.8 \%$ of the change in OCB. This result provides support for $\mathrm{H} 1 \mathrm{~d}$, which suggested that employee perception of equality positively influences their OCB. As for 'accountability', 'transparency' and 'participation-criticism' these dimensions have the least amount of influence on OCB $(18.7 \%, 12.1 \%$ and $11.2 \%$, respectively). The remaining hypotheses, H1a (employee perception of 'participation-criticism' positively influences their OCB), H1b (employee perception of 'transparency' positively influences their OCB) and H1e (employee perception of 'accountability' positively influences their OCB) are also supported.

\section{Discussion}

Research on OD and its influence on OCB of serviceoriented employees is limited. Thus, this study aimed at addressing this gap in the literature by empirically testing the relationship between OD and OCB amongst banking sector employees in Turkey. Firstly, the results of the study disclosed that the mean score for the perceived levels of OCB was 3.52. Even though this score is above the 3.00 mid-point score, it can only be considered as moderate. This finding suggests that banking sector employees perceive themselves to exhibit only moderate levels of voluntary behaviour and actions in their workplace. OD sub-dimensions' mean scores also showed that banking sector employees perceived 'transparency' and 'accountability' in their organisation at a higher democratic level with mean scores above 3.50. Because service-oriented employees are expected to deliver quality services to customers and deal with customer requests and problems successfully, their ability to access information and to be informed of work-related decisions is vital. Likewise, especially in financial institutions like banks, accountability is an important concept that goes beyond the employees and extends to customers and society as a whole. The sub-dimensions 'justice', 'participationcriticism' and 'equality', however, were perceived to be at a lower democratic level, with mean scores less than 3.50. Organisational democracy calls for justice and equality especially in the distribution of income because perceptions of income gaps amongst employees will result in the failed embellishment of a democratic organisation, which in turn will influence employee behaviour. In addition, democracy calls for participation in the decision-making process and the ability to criticise and comment on work policies, procedures

TABLE 4: Correlation analysis: Organisational democracy and organisational citizenship behaviour relationship.

\begin{tabular}{lccccccc}
\hline Variables & Correlation Statistics & OD & Participation-criticism & Transparency & Justice & Equality & Accountability \\
\hline OCB & r & 0.257 & 0.245 & 0.201 & 0.329 & 0.404 & 0.309 \\
& P & 0.000 & 0.000 & 0.000 & 0.000 & 0.000 \\
& N & 240 & 240 & 240 & 240 & 240 \\
\hline
\end{tabular}

$\mathrm{OD}$, organisational democracy; OCB, organisational citizenship behaviour; $\mathrm{T}, t$-statistic; $\mathrm{P}, p$-value; $\mathrm{F}, \mathrm{F}$-statistic.

TABLE 5: Regression analyses: Influence of organisational democracy on organisational citizenship behaviour.

\begin{tabular}{|c|c|c|c|c|c|c|c|}
\hline Variables & Regression Statistics & OD & Participation-criticism & Transparency & Justice & Equality & Accountability \\
\hline \multirow[t]{6}{*}{ ОСВ } & Adjusted $\mathrm{R}^{2}$ & 0.245 & 0.112 & 0.121 & 0.226 & 0.218 & 0.187 \\
\hline & $f$ & 143.248 & 55.972 & 61.343 & 129.213 & 123.090 & 101.450 \\
\hline & $\mathrm{p}$ & 0.000 & 0.000 & 0.000 & 0.000 & 0.000 & 0.000 \\
\hline & $\beta$ & 0.497 & 0.337 & 0.351 & 0.478 & 0.469 & 0.434 \\
\hline & $\mathrm{t}$ & 11.969 & 7.481 & 7.832 & 11.367 & 11.095 & 10.072 \\
\hline & $\mathrm{p}$ & 0.000 & 0.000 & 0.000 & 0.000 & 0.000 & 0.000 \\
\hline
\end{tabular}

$\mathrm{OD}$, organisational democracy; OCB, organisational citizenship behaviour; $\mathrm{T}, t$-statistic; $\mathrm{P}, p$-value; F, F-statistic 
and practices. The mean score for each OD sub-dimension, as well as the overall OD mean score (3.40), is an indication that banking sector employees' perceptions of OD were not of a high level and they did not consider their organisation to be a democratic one. This emphasises the fact that all five subdimensions of OD need to exist in organisational life to instil a democratic atmosphere.

The relationship between perceptions of OD and citizenship behaviour was analysed through correlation and linear regression analysis. The study findings point out that perception of OD contributed to $25 \%$ of the employees' citizenship behaviour. This suggests that other variables are also influential over OCB. The study also shows that all of the OD sub-dimensions also influence OCB. This suggests that managers should take measures to practise democracy in the workplace in order to ensure an effective functioning organisation. Of the OD sub-dimensions examined, the dimension 'justice' is the most influential on OCB. Various studies have identified a positive and significant relationship between organisational justice and OCB (Arslantaş \& Pekdemir 2007; Geçkil \& Tikici 2016; Moorman, Blakely \& Niehoff 1998), which supports the results of this study. Therefore, measures such as management displaying sensitivity with regard to the implementation of procedures and interpersonal relationships can increase the perceptions of OD. Likewise, through regulating the distribution of rewards and punishment perceptions of democracy can also be heightened. The results of this study also indicate that 'equality' has a substantial influence on OCB. Previous research has shown that employees tend to exhibit more OCB when they perceive more procedural fairness in decisionmaking (Moorman et al. 1998). This suggests that when employees perceive that they are being treated equally in the workplace, they are more willing to display voluntary behaviour. This suggests that management should make the effort to stipulate equality in the workplace through ensuring that treatment towards employees is established as per the criteria designated for equality, for instance knowledge, performance and skills. This will increase the perceptions of democracy in the workplace, which in turn will reflect on the citizenship behaviour of the employees. Likewise, OD and in turn OCB can also be strengthened through management's efforts to display their acceptance of liability for the consequences of courses of action (accountability), thus creating a stronger and sounder relationship between an organisation's management and its employees. According to Hall et al. (2009), accountability and OCB are distinct constructs and the relationship between accountability and performance is an interesting one that warrants closer scrutiny. Karaaslan, Özler and Kulaklıoglu (2009) found that information sharing (transparency) positively contributed to OCB. This finding runs parallel to the findings of this study, indicating that when organisational information is freely shared and is accessible to all organisational members, the perceptions of OD can be heightened. Porter et al. (1996) draw attention to the fact that participation in decisionmaking can lead to engagement in OCB. This is consistent with the results of this study. Therefore, providing a suitable environment for discussions and the development of solutions to problems being faced and being open to criticism from employees (participation-criticism) will heighten employee perceptions of OD reflecting on their OCB.

None of the demographic variables (e.g. tenure, gender) measured in the study was found to be statistically significantly related to OD or OCB.

Organisational citizenship behaviour is a concept that has important organisational outcomes and the present study incorporates OD with OCB. The findings of this study propose that managers should seriously appreciate the implication of $\mathrm{OD}$ and $\mathrm{OCB}$, and take precautions to create an environment in which OD is perceived to enhance $\mathrm{OCB}$ within their organisations. The practice of OD must be sincere if it is to have any worthwhile significance to employees and their citizenship behaviour, and in turn organisational performance in the long term.

\section{Conclusion}

Organisational citizenship behaviour is a significant issue that can contribute to the existence of an organisation. Organisational citizenship behaviour in the service industry is more important than in the manufacturing industry because service-oriented employees are in constant direct contact with customers (Bartel 2004), and their behaviour can eventually improve (or diminish) organisational performance. So as to meet or surpass customers' expectations, serviceoriented employees have to adjust their work behaviour to cope with the highly individualised nature of customer needs, identifying the vital role of OCB in service industries (Stamper \& Van Dyne 2003). In this sense, it is essential for banks to appreciate the variables that significantly support the creation of favourable behaviour within the organisation. Banks should develop an appropriate environment that will guide employees' actions to stimulate OCB. Through this study, it can be seen that OD is an important variable that can be used by managers to facilitate the favourable behaviour of employees and to promote the sense of citizenship that employees feel towards their organisation, which, in turn, will lead to enhanced organisational performance.

\section{Limitations of the study and recommendations for further research}

This study, however, has some limitations. Firstly, the study was limited to bank employees at one bank in one city in Turkey. Therefore, this limits the generalisability of the findings and it is recommended that future researchers consider conducting research on banks in the whole of Turkey. Secondly, this study used cross-sectional data; therefore, it is not possible to establish causality between OD and OCB. It is recommended that future researchers consider using a longitudinal design to gather data, thus allowing for causal relationship statements. Furthermore, it is recommended that researchers also investigate other 
variables that may be influential on OCB, such as organisational commitment, organisational culture and job satisfaction. There is limited research in the literature relating OD and OCB and so this needs to be explored further. This study is a basis for further research in this field.

\section{Acknowledgements}

This work is based on the Doctorate degree dissertation by Özhan Tokay entitled 'The influence of organizational democracy and organizational belongingness on the job satisfaction and organizational citizenship behaviour relationship: A study of the banking sector', which will be submitted (planned date of completion: November 2018) to the Near East University, North Cyprus. The co-author of this article is (S.Z.E.) the supervisor of the dissertation.

\section{Competing interests}

The authors declare that they have no financial or personal relationships that may have inappropriately influenced them in writing this article.

\section{Authors' contributions}

Both the authors contributed equally to the planning, researching, structuring, writing and the revision of the manuscript.

\section{References}

Akdoğan, A.A. \& Köksal, O., 2014, 'Aidiyet algısının örgütsel vatandaşlık davranış üzerindeki etkisinde yöneticiye güvenin aracılık rolü [The role of trust towards the manager in the influence of sense of belonging on organizational citizenship behavior]', Atatürk Üniversitesi Sosyal Bilimler Enstitüsü Dergisi 18(1), 25-43.

Ali, U. \& Waqa, S., 2013, 'Teachers' organizational citizenship behaviour working under different leadership styles', Pakistan Journal of Psychological Research 28(2), 297-316.

Arslantaş, C. \& Pekdemir, I., 2007, 'Dönüşümcü liderlik, örgütsel vatandaşlık davranış ve örgütsel adalet arasındaki ilişkileri belirlemeye yönelik görgül bir araştırma' [An empirical study to determine the relationship between transformational leadership, organisational citizenship behaviour and organisational justice]', Anadolu Üniversitesi Sosyal Bilimler Dergisi 7, 262-268.

Bakan, I, Kara, E. \& Güler, B., 2017, 'The effects of organizational democracy perception on employees' intrapreneurship performance: An empirical in hote firms in Marmaris', HAK-is Uluslararası Emek ve Toplum Dergisi 6(14), 115-138.

Bartel, A., 2004, 'Human resource management and organizational performance: Evidence from retail banking', Industrial and Labor Relations Review 57(2), 181-203. https://doi.org/10.1177/001979390405700202

Basım, H. \& Şeşen, H., 2015, 'Örgütsel vatandaşlık davranışı ölçeği uyarlama ve karşılaştrma çalışması [An adaptation and comparison of organizational citizenship behavior scale]', Yönetim Bilimleri Dergisi 12(23), 237-278.

Borman, W.C. \& Motowidlo, S.J., 2014, Organizational citizenship behaviour and contextual performance: A special issue of human performance, Psychology Press, New York.

Boxall, P. \& Purcell, J., 2011, Strategy and human resource management, Palgrave Macmillan, New York.

Coşan, P.E. \& Gülova, A.A., 2014, 'Örgütsel demokrasi [Organizational democracy]', Yönetim ve Ekonomi 21(2), 231-248.

Deluga, R.J., 1995, 'The relationship between attributional charismatic leadership and organizational citizenship behaviour', Journal of Applied Social Psychology 25(18) 1652-1669. https://doi.org/10.1111/j.1559-1816.1995.tb02638.x

Eyupoglu, S.Z., 2016, 'The organizational citizenship behaviour of academic Staff in North Cyprus', Procedia Economics and Finance 39, 701-704. https://doi org/10.1016/S2212-5671(16)30280-5

Farh, J.L., Earley, P.C. \& Lin, S.C., 1997, 'Impetus for action: A cultural analysis of justice and organizational citizenship behavior in Chinese society', Administrative Science Quarterly 42(3), 421-444. https://doi.org/10.2307/2393733

Folger, R., 1977, 'Distributive and procedural justice: Combined impact of "voice" and improvement on experienced inequity', Journal of Personality and Socia Psychology 35(2), 108-119. https://doi.org/10.1037/0022-3514.35.2.108
Forcadell, F.J., 2005, 'Democracy, cooperation and business success: The case of Modragon Corporacion Cooperativa', Journal of Business Ethics 56, 255-274. https://doi.org/10.1007/s10551-004-5094-5

Geçkil, T. \& Tikici, M., 2015, 'Örgütsel demokrasi ölçeği geliştirme çalışması [A study on developing the organizational democracy scale]', Amme Idaresi Dergisi 48(4), 41-78.

Geçkil, T. \& Tikici, M., 2016, 'Hospital employees' organizational democracy perceptions and its effects on organizational citizenship behaviors', Asian Pacific Journal of Health Sciences 3(2), 123-136.

Graham, J.W., 1991, 'An essay on organizational citizenship behaviour', Employee Responsibilities and Rights Journal 4(4), 249-270. https://doi.org/10.1007/ BF01385031

Hair, J., Black, W., Babin, B., Anderson, R. \& Tatham, R., 2006, Multivariate dato analysis, 6th edn., Pearson Prentice-Hall, Upper Saddle River, NJ.

Hall, A.T., Zinko, R., Perryman, A.A. \& Ferris, G.R., 2009, 'Organizational citizenship behaviour and reputation: Mediators in the relationship between accountability and job performance and satisfaction', Journal of Leadership and Organizationa Studies 15(4), 381-392.

Harrison, J.S. \& Freeman, R.E., 2004, 'Democracy in and around organizations: Is organizational democracy worth the effort?', Academy of Management Executive 18(3), 49-53.

Harrison, S. \& Edward, R., 2004, 'Is organizational democracy worth the effort', The Academy of Management Executive 18(3), 49-53.

Hendry, C., 2012, Human resource management, Routledge, New York.

Karaaslan, A., Özler, E.D. \& Kulaklıoğlu, A.S., 2009, ‘Örgütsel vatandaşlık davranışı ve bilgi paylaşımı arasındaki ilişkiye yönelik bir araştırma [A study on the relationship between organizational citizenship behavior and knowledge sharing]', Afyon Kocatepe Üniversitesi, i.i.B.F. Dergisi 11(2), 135-160.

Katz, D. \& Kahn, R.L., 1966, The social psychology of organizations, Wiley, New York.

Kerr, J.L. \& Caimano, V.F., 2004, 'The limits of organizational democracy', The Academy of Management Review 18(3), 81-97.

Kesen, M., 2015, 'Investigating the effects of organizational democracy and organizational identification on job satisfaction: A field study on retail industry', IIB International Refereed Academic Social Sciences Journal 6(19), 61-89. https:// doi.org/10.17364/IIB.20151912613

King, E., George, J. \& Hebl, M., 2005, 'Linking personality to helping behaviors at work: An interactional perspective', Journal of Personality 73, 585-607. https:// doi.org/10.1111/j.1467-6494.2005.00322.x

Konovsky, M.A. \& Pugh, S.D., 1994, 'Citizenship behavior and social exchange', The Academy of Management Journal 37(3), 656-669.

LePine, J.A., Erez, A. \& Johnson, D.E., 2002, 'The nature and dimensionality of organizational citizenship behavior: A critical review and meta-analysis', Journal of Applied Psychology 87, 52-65. https://doi.org/10.1037/00219010.87.1.52

Lindkvist, L. \& Llewellyn, S., 2003, 'Accountability, responsibility and organization', Scandinavian Journal of Management 19, 251-273. https://doi.org/10.1016/ Scandinavian Journal of

Mitchell, T.R., Hopper, H., Daniels, D., George-Falvy, J. \& Ferris, G.R., 1998, 'Power, accountability and inappropriate actions', Applied Psychology: An International Review 47, 497-517.

Morrison, E.W., 1994, 'Role definition and organizational citizenship behaviour: The importance of the employee's perspective', Academy of Management Journal 37(6), 1543-1567.

Moorman, R.H., Blakely, G.L. \& Niehoff, B.P., 1998, 'Does perceived organization support mediate the relationship between procedural justice and organizational citizenship behaviour?', Academy of Management Journal 41(3), 351-357.

Organ, D. \& Ryan, K., 1995, 'A meta-analytic review of attitudinal and dispositional predictors of organizational citizenship behaviors', Personnel Psychology 48, 775-802. https://doi.org/10.1111/j.1744-6570.1995.tb01781.x

Organ, D.W., 1988, Issues in organization and management series, organizationa citizenship behavior: The good soldier syndrome, Lexington Books/D. C. Heath and Co., Lexington, MA/England.

Park, R. \& Searcy, D., 2012, 'Job autonomy as a predictor of mental wellbeing: The moderating role ofquality-competitive environment', Journal of Business and Psychology 27(3), 305-316. https://doi.org/10.1007/s10869011-9244-3

Podsakoff, P.M., Mackenzie, S.B., Moorman, R.H. \& Fetter, R., 1990, 'Transformational leader behaviors and their effects on followers' trust in leader, satisfaction and organizational citizenship behavior', The Leadership Quarterly 1(2), 107-142. https://doi.org/10.1016/1048-9843(90)90009-7

Podsakoff, P.M., MacKenzie, S.B., Paine, J.B. \& Bachraeh, D.G., 2000, 'Organizational citizenship behaviors: A critical review of the theoretical and empirical literature and suggestions for future research', Journal of Management 3, 513-563. https:// doi.org/10.1177/014920630002600307

Porter, L.W., Lawler, E.E. \& Hackman, J.R., 1996, 'Ways groups influence individual work effectiveness', in R.M. Steers, L.W. Porter \& G.A. Bigley (eds.), Motivation and leadership at work, pp. 346-354, McGraw-Hill, New York.

Redman, T. \& Snape, E., 2005, 'I to wed: The role of consciousness transformation in compassion and altruism', Journal of Management Studies 42(2), 301-328. https://doi.org/10.1111/j.1467-6486.2005.00498.x

Sekaran, U. \& Bougie, R., 2013, Research methods for business: A skill-building Approach, Wiley, New York. 
Shore, L.M. \& Barksdale, K., 1998, 'Examining degree of balance and level of obligation in the employment relationship: A social exchange approach', Journal of Organizational Behavior 19(1), 731-744. https://doi.org/10.1002/(SICI)10991379(1998)19:1+\%3C731::AID-JOB969\%3E3.0.CO;2-P

Somech, A. \& Drach-Zahavy, A., 2004, 'Exploring organizational citizenship behaviour from an organizational perspective: The relationship between organizational learning and organizational citizenship behaviour', Journal of Occupational and Organizational Psychology 77(3), 281-298. https://doi. org/10.1348/0963179041752709

Stamper, C.L. \& Van Dyne, L., 2003, 'Organizational citizenship: A comparison between part-time and full-time service employees', Cornell Hotel and Restaurant Administration Quarterly 44(1), 33-42. https://doi.org/10.1016/ S0010-8804(03)90044-9

Tutar, H. \& Sadykova, G., 2014, 'Örgütsel demokrasi ve örgütsel muhalefet arasındaki ilişki üzerine bir inceleme [An investigation of the relationship between organizational democracy and organizational dissent]', işletme Bilimi Dergisi 2(1) $1-16$.
Ünüvar, T.G., 2006, 'An integrative model of job characteristics, job satisfaction, organizational commitment, and organizational citizenship behavior', Unpublished Doctoral dissertation, Middle East Technical University, Ankara.

Weber, W.G., Unterrainer, C. \& Schmid, B.E., 2009, 'The influence of organizational democracy on employees' socio-moral climate and pros orientations', Journal of Organizational Behavior 30(8), 1127-1149. https://do org/10.1002/job.615

Yazdani, N., 2010, 'Organizational democracy and organization structure link: Role of strategic leadership and environmental uncertainty', Business Review 5(2), 51-73.

Yıldırım, F., 2003, 'Çalışma yaşamında örgüte bağııık ile örgütsel adalet, örgüt temelli özsaygı ve bazı kişisel ve örgütsel değişkenlerin ilişkisi [The relationship of organizational commitment and organizational justice in working life on organizational based self-esteem and some personal and organizational variables]', Mülkiye 25(2), 371-402.

Yoon, M.H. \& Suh, J., 2003, 'Organizational citizenship behaviours and service quality as external effectiveness of contact employees', Journal of Business Research 56(8), 597-611. https://doi.org/10.1016/S0148-2963(01)00290-9 